\title{
Interacting among state and public sphere in contemporary history of $\operatorname{Iran}^{1}$
}

\author{
Hossien Mohammadzadeh
}

\author{
Assistant Professor, Department of Social science, Payame Noor University, PO BOX 19395 - \\ 3697, Tehran, IRAN \\ E-mail address: \\ h.mohammadz11@gmail.com
}

Keywords: public sphere, Iran, Contemporary history, power

ABSTRACT. The goal of this study is interaction among state and public sphere as part of civil society in Iran contemporary periods. Public sphere is an index for open society and transformation toward democracy. Habermas theory about public sphere were my guide theoretical framework, the methodology was documental, data collected from historian documents. Results of study shows that public sphere in contemporary history of Iran is very weak and periodical, public sphere sunrise and fall by change of power and government, the role of governor's politician in the opening of this space is important.

\section{INTRODUCTION}

The public sphere is an area in social life where individuals can come together to freely discuss and identify societal problems, and through that discussion influence political action. It is "a discursive space in which individuals and groups congregate to discuss matters of mutual interest and, where possible, to reach a common judgment."(Gerard, 1998). "We call events and occasions 'public' when they are open to all, in contrast to closed or exclusive affairs"(Habermas, 1989).

Theoretical framework

Most contemporary conceptualizations of the public sphere are based on the ideas expressed in Habermas' book The Structural Transformation of the Public Sphere, The German term (public sphere) encompasses a variety of meanings and it implies a spatial concept, the social sites or arenas where meanings are articulated, distributed, and negotiated, as well as the collective body constituted by, and in this process, "the public" (Negt,Kluge,1993). The work is still considered the foundation of contemporary public sphere theories, and most theorists cite it when discussing their own theories.

The bourgeois public sphere may be conceived above all as the sphere of private people come together as a public; they soon claimed the public sphere regulated from above against the public authorities themselves, to engage them in a debate over the general rules governing relations in the basically privatized but publicly relevant sphere of commodity exchange and social labor(Habermas,1989)

Through this work, Habermas gave a historical-sociological account of the creation, brief flourishing, and demise of a "bourgeois" public sphere based on rational-critical debate and discussion:(Berdal,2004). Habermas stipulates that, due to specific historical circumstances, a new civic society emerged in the eighteenth century. Driven by a need for open commercial areas where news and matters of common concern could be freely exchanged and discussed - accompanied by

1-This article adopted from a documentary research that supported by deputy research o f Kurdistan Payam Noor University. 
growing rates of literacy, accessibility to literature, and a new kind of critical journalism separate domain from ruling authorities started to evolve across Europe. "In its clash with the arcane and bureaucratic practices of the absolutist state, the emergent bourgeoisie gradually replaced a public sphere in which the ruler's power was merely represented before the people with a sphere in which state authority was publicly monitored through informed and critical discourse by the people (Habermas, 1989).

In his historical analysis, Habermas points out three so-called "institutional criteria" as preconditions for the emergence of the new public sphere. The discursive arenas, such as Britain's coffee houses, France's salons and Germany's Tischgesellschaften "may have differed in the size and compositions of their publics, the style of their proceedings, the climate of their debates, and their topical orientations", but "they all organized discussion among people that tended to be ongoing; hence they had a number of institutional criteria in common (Habermas, 1989:36).

1. Disregard of status: Preservation of "a kind of social intercourse that, far from presupposing the equality of status, disregarded status altogether. Not that this idea of the public was actually realized in earnest in the coffee houses, salons, and the societies; but as an idea it had become institutionalized and thereby stated as an objective claim. If not realized, it was at least consequential."

2. Domain of common concern: "... discussion within such a public presupposed the problematization of areas that until then had not been questioned. The domain of 'common concern' which was the object of public critical attention remained a preserve in which church and state authorities had the monopoly of interpretation (Habermas, 1989)The private people for whom the cultural product became available as a commodity profaned it inasmuch as they had to determine its meaning on their own (by way of rational communication with one another), verbalize it, and thus state explicitly what precisely in its implicitness for so long could assert its authority."

3. Inclusivity: However exclusive the public might be in any given instance, it could never close itself off entirely and become consolidated as a clique; for it always understood and found itself immersed within a more inclusive public of all private people, persons who insofar as they were propertied and educated - as readers, listeners, and spectators could avail themselves via the market of the objects that were subject to discussion. The issues discussed became 'general' not merely in their significance, but also in their accessibility: everyone had to be able to participate. Wherever the public established itself institutionally as a stable group of discussants, it did not equate itself with the public but at most claimed to act as its mouthpiece, in its name, perhaps even as its educator - the new form of bourgeois representation" .Gerard Hauser proposed a different direction for the public sphere than previous models. He foregrounds the rhetorical nature of public spheres, suggesting that public spheres form around "the ongoing dialogue on public issues" rather than the identity of the group engaged in the discourse.

In Rethinking the Public Sphere, Nancy Fraser offers a feminist revision of Habermas' historical description of the public sphere, and confronts it with "recent revisionist historiography" (Fraser, 1990).

In Iran, we have not considerable research about public sphere. Sarayi and Alirazanjhad (2007) doing a research about women social space that closed to public sphere. They used historical methods for their research. Research show social spaces divide in two parts, men and women. Some of these space women participated and tailing about every day live events, like public bath, bazaar and Holy spaces. 
Armaky and Amani (2004) conducted a researched about public sphere among social science students in Tehran. They interview with four student organization that activated post of reform period in Iran. Data shows public sphere shape and student a bout, university managements, state, civil society.

The goal of this article is about effective and consequences opening political spaces on public sphere and social activity in contemporary of Iran?

\section{METHODOLOGY}

The method of this study is historical. In the historical study, we a question about past events. Data gathering by historical documents. We attention to change in politics and elite politician and transformation and changes in public sphere and civil society.

\section{RESULTS}

In Iran, experience of public sphere is not like west societies. But public sphere and civil society overlaps to each others. In the Qajar era some of Iranian political elite, merchants and intellectual inform and awareness of modernity. They try to practically in the country, change the behavior of governors and attention to the civil society. These processes were not simple and engage with many obstacles. But their activity consequence in Mashrotyat (constitional) period.

In the consteitionual period many worked to be doing: the King power has been limited, power divided, people for the first time choosing their representative, political party growth and magazine and newspaper sunrise, but this time were short and dictatorship come back.

Reza Shah come to power, he want to modernization of Iran, but he take some part of modernity and ignored some part one. He concentrated on regular army, educated systems, bureaucracy and lay out political developments. In this era some military and ethnic uprising suppress, civil society closed and social activist fly or to be in prison. big power invasion to Iran and country occupied by Russian and Britain. Reza shah flies from country and power weaken. Civil society reactivated.

Mosadiq come to power and revival public sphere and civil society. He was a nationalist. He tries to nationalized oil company and other companies. he allowed political party to activity. Opposision began to work and news paper publishing in the society. Some of these newspapers belong to the public sphere and other political party. In this time 15 political party and 4000 newspaper activated in the society(Afkhami,2003). The benefits of big power come to dangerous. They coup data against his government and defeated it. Mohammad Reza Shah get the power.

When he comes to power he was very young and his government was weak. Step by step he be empower and weak society, he was very interested to technology and western country, don't attention to the civil society, later he began to white revolution as name of shah and people revolution. He began to land reform in the country. At the results many peasant take land and feudal defeated. He suppress civil and cultural and oppositions political activities. The price of oil comedown and people participated against government. In the 1989 the Islamic Republic of Iran comes to power.

Post of revolution government's powers destroys and social movement began to activity. Much political and social party uprising. News paper and magazine published and distribution an all corner of country. These periods were a haven of civil society in Iran. Iraq invasion to Iran and everything come back to firs line. 
In the time of war people attention to the enemy and defeat them. War continues until eighth years, many young killed and injured. Country encounters many costs. When the Rafsanjani and Building era began many of infrastructures of country were destroyed. He started to building infra structural, and country takes many loans from World Bank. He sustains closed society.

People needs a new period and they choose Mohammad Khatami as presidents of Iran. His motto was civil society. He allow to political party, newspaper, studend and non government organization to be activated. Post of time conservative forces encounter him and hid governments. This time flourished but come down very soon.

When the conservative return to power. They eradicated civil society and public sphere. Everything destroyed or going to underground.

Now is Rohany government and it is very soon that we telling anything about future of civil society of Iran.

\section{CONCLUSION}

This is correct that civil society in Iran fellow political change. As one of the Iranian thinker told when nation government come to power, the civil society activated and when national government fall, the public sphere far away. Public sphere in the contemporary of Iran until now is a concepts. But this is corrects that political power effected and spread and can closed this spaces. In the qajar, Raza shah and Mohammad Reza shah the power is centralized and civil society no any sign. But in the constitutional period and Mosadiq and in sunrise of Islamic republic of Iran we see public sphere. In the during the time. Public sphere up and down, but every time it return powerful than last one.

\section{References}

[1] Afkhami H(2004) political party, media party and independents newpapers, in the book of Iran social problems(Persian) Tehran,Ageh,

[2] Amsden, A (1989) Asia s Next Giant, South Korea and Industrialization, New York, Oxford university press.

[3] Armaky A,Amamyi Y(2004) evolution of public sphere and rational dialogue, Iranian sociological magazine,no, 1,spring.

[4] Baiocchi G (2003) Emergent Public Sphere, American sociological review, vol 68.

[5] Berdal, S.R.B. (2004), Public deliberation on the Web: A Habermasian inquiry into online discourse (thesis), Oslo: University of Oslo,

[6] Evans (1994) Embedded Autonomy, State and Industrial transformation, Uncpress, New York.

[7] Fraser N(1990)Rethinking of public sphere, a contribution to the criterion of actually existing democracy, in Craig Calhn,Cmbridge mass,pp 109-142

[8] Gerard (1998) Vernacular Dialogue and rhetorically of public opinion, Communication monographs, 65, pp 83-107.

[9] Gill G(2000) The Dynamics of Democratization: Toward consolidation, John Hopkins university press.

[10]Habermas $\mathrm{j}$ (1989)the structural transformation of public sphere, Thomas burger and Fredrick Lawrence, it Press,USA.

[11] Khaniky H(2002) Power, civil society and media, Tehran, Tarh naw.

[12] Negt O, Kluge A (1993) public sphere and experience, toward an analysis of the bourgeois' and proletarian public sphere, Minneapolis, university of Minnesota press.

[13] Nirumand B (2000) Iran-report, nr 11/2003, Berlin.

[14] Sarayi H,Alirezanajad(2007) women in the public sphere,Namayi olum Ijtimaiy.no,30.spring.

[15] Taylore C (1992) Modernity and the rise of the public sphere, Stanford university. 